\title{
Impact of Road and Drainage Infrastructure on the Resident Population of Otukpa Urban, Otukpa L.G.A of Benue State, Nigeria
}

\author{
*Eze, Basil U. (Ph.D) and Ameh, Ekere J. \\ Department of Geography and Meteorology, Faculty of Environmental Sciences Enugu State University of \\ Science and Technology, Enugu State, Nigeria.
}

\begin{abstract}
Roads And Drainages Are Indispensable Infrastructures In Our Urban, As Well As Rural Areas. Their State Should Be A Source Of Concern To All Well-Meaning People Of Nigeria. This Research Work Therefore Sought To, And Exposed The State Of Roads And Drainages In Otukpo Urban, Benue State Of Nigeria. The Data Used In This Research Work Were Obtained From Primary And Secondary Sources. The Study Found A High Level Of Dissatisfaction (93:23\%) On The Level Of Government's Commitment To Construction And Maintenance Of Roads And Drainages. This Level Of Disenchantment Is Precipitated Upon The High Level Of Deterioration (70.68\% And 66.22\%) Of Otukpo Urban Roads And Drainages, Respectively. The Researcher Recommends, Among Others, Good Governance And A Total Change Of Orientation On The Part Of The People As The Panacea For This Situation. It Is Hoped That If The Relevant Authorities And Other Stakeholders Study The Research Work Well And Religiously Apply The Recommendations Proffered Therein, It Will Help In No Small Measure In Instituting A Friendly Environment That Is Delightful And Sustainable To The Benefit Of Humanity.
\end{abstract}

Keywords: Roads, Drainages, Maintenance, Benue State, Good Governance

\section{Introduction}

In the early times, roads and drainages were not popular, people moved about in bushes. Later, tracks were developed to ease communication. Road construction itself started at about $312 \mathrm{BC}$ in Rome when about 50,000 miles of roads was built (Cedergren, 1974).

The beginning of civilization marked mankind's attempt to conquer his environment, to make life more pleasant for living. This attempt came several years ago and it is seemingly unending as more knowledge has been acquired and more searches are still being made to register more significant conquest and innovation (Ogwuche, 2005). Regarding these advances, therefore, acquired knowledge and technology have been needed by man to develop the landscape far beyond its natural form to an extent that most natural obstacles and harzards or phenomena can be prevented, controlled or averted. Man's activities on the landscape and other influences on natural phenomena have actually kept him far from the beast. No doubt, man, presently, has excelled in the area of road and drainage construction (Owolabi, 1995).

Roads and drainages are important aspect of infrastructural development of any society. In a humanly populated environment, they are essential for any meaningful socio-economic activities as human beings are itinerant in nature (Uchegbu, 2000). Being the most universal form of transport, people therefore need roads to be able to communicate with one another, carry out transactions (Udongwu, 2002). They also need drainages, which collect unwanted water and other liquid waste and channel such into an appropriate place (Nmegbu, 2001). This ensures that roads are not waterlogged, and residential (and other) areas are properly drained of wastewater.

However, natural harzards, for instance, flood, have attracted serious attention in man's inhabited environment. Man too has tremendously influenced the state of his environment either positively or negatively through his activities such as deforestation, indiscriminate erection of structures, and reluctance to maintain even those structures he has put in place for his own benefits. In urban centres, if the road network is properly established, drainage system well planned and constructed, and both government and the people join hands to maintain them, then such a place will definitely appear delightful (Offiong, 1997). This was the dream of the General Olusegun Obasanjo's military regime in the late 70's when it ordered massive construction of trunk "A" roads across Nigeria. Thus, one of such roads, which link Eastern Nigeria with the north through Otukpo, is now regarded as the major road in Otukpo Urban. Together with the intra-city roads, a network of roads is formed. Consequently, some drainage now exists as a mitigating measure against flood, run-offs and stagnant water. This research therefore brings to light the state of these roads and drainages in the research area with a view to drawing the attention of government and indeed the general public to their current condition. Their current state 
will determine whether or not the stakeholders need to do any adjustment in their approach to these structures to ensure that man continues to derive maximum satisfaction from them.

\section{Statement of the research problem}

Otukpo is an ancient town. It is the headquarters of the Idoma nation. Because of this strategic role coupled with the fact that the town lies between southern and northern Nigeria, it is natural that people should be curious about what goes on in the town. As its population grows, the need for roads and drainages to carter for the rising demand of the inhabitants also grows. In the light of this, there is a pressure on the available roads and drainages, culminating in putting these structures in a particular state. Therefore, the problem of this research is to identify this state and highlight its impact on the people.

\section{Geographical Location}

\section{Materials and methods}

Otukpo Urban area is centrally situated between the Tiv (in Benue State) and the Igala (in Kogi State). It is about $100 \mathrm{~km}$ south of Makurdi (the state capital). It is situated around the intersection of East-North railway and on the Enugu - Makurdi road, and is located at approximately between latitudes $07^{0} 38^{\prime}-07^{0} 54^{\prime}$ North and longitudes $08^{0} 40^{\prime}-08^{0} 52^{\prime}$ East. It is bounded in the north by Apa L.G.A., in the east by Gwer West and Gwer L.G.As, in the South by Okpokwu and Oju L.G.As, and in the West by Kogi State (Ogwuche, 2005).

\section{Physical Characteristics}

Otukpo Urban area is anchored on a laterite hill, about $152-213 \mathrm{~m}$ above sea level. Its main topographical features are the plain land stretching from Akpa district in the South to Agatu district in the north. The climate is a tropical hinterland type (Iloeje, 1965). It lies in the derived savannah zone but the complex of trees and grasses, which make up the zone, has led to the region being termed 'mixed leguminous wooded savannah' (Areola, 1978). Its average annual rainfall lies between 1250-150mm. there are two distinct seasons the wet/rainy season and the dry season starts in November and ends in March. Temperature, according to Areola (1978) fluctuates between $23^{\circ} \mathrm{C}$ to $30^{\circ} \mathrm{C}$.

Otukpo Urban, like most of Nigerian towns and cities, has two major areas - the informal or irregular residential area and the formal or regular residential area. The former comprises settlements such as Ojira, Oweto, Eupi, Babylon, Sabon Gari, Zone HB, Effa, and Ogwuonu-Igbalapa. These are the slum areas where majority of Otukpo Urban residents live. On the other hand, the formal or regular residential area comprises mainly the Government Reserved Area (GRA). This is where the rich and affluent citizens of Idomaland live. This area manifests some evidence of physical planning in terms of housing, water supply and electricity supply (Ogwuche, 2005).

\section{Research Population Size}

The following different parts of Otukpo Urban have been chosen to form the research population: GRA, Effa, Zone HB, Ogwuonu-Igbalapa, Sabon Gari, Eupi, Ojira, Babylon, and Oweto. Those left cut include: Ikobi, Asa, Hausa Quarters, Ampia and Igbanomaje.

Apart from the roads and drainages (where available) within the sampled areas, users of these structures in these areas also form part of the population size. In addition, government bodies responsible for the effective functioning of roads and drainages are part of the population size. They include the following:

i. Benue State Ministry of Works, Zonal Office, Otukpo,

ii. Federal Road Safety Corps, Otukpo Unit Command, and

iii. Environmental Health Department of Benue State Ministry of Health, Zonal Office, Otukpo.

\section{Sources of Data}

Data for this research were collected from two sources: primary sources and secondary sources.

\section{Primary Sources}

These include questionnaires, oral interviews, and personal observations. Through these sources, data for the research were generated. Data gathered from primary sources are referred to as primary data.

i. Questionnaire: the questionnaire contains, among others, questions according the state of Utokpo Urban roads and drainages; whether these structures are maintained; and impact they have on the socio-economic and general well-being of the research population.

ii. Oral interview: road and drainage users were interviewed directly to obtain on-the-spot-response from them. These users extend to the organized private sector like the 'Okada' riders. Also interviewed include government bodies such as the Federal Road Safety Corps (FRSC); Ministry of Works, Zonal Office, Otukpo; and Environmental Health Department of Ministry of Health, Zonal Office, Otukpo. 
iii. Personal Observation: One of the researchers has been living in Otukpo towns since 1983. He is therefore very familiar with virtually all nooks and crannies of Otukpo Urban. With this singular but important advantage, he can give an incontrovertible and unequivocal assessment of the state of roads and drainages in the study area and its social, economic psychological, health (and other) impact on the research population.

\section{Data analysis techniques}

In this research; tables are used to arrange the data collected in orderly manner, and are also used in data presentation. This is because apart from being effective in presenting the result of the research, tables are also helpful in showing empirical distribution of the variables in the questionnaire.

Simple percentages are used in the analysis of data so as to ascertain the number of respondents that fall into a response category or possess some defined characteristics.

\section{Results}

A total of 150 questionnaires were distributed, out of which 133 were filled by respondents and retrieved from them. Of the 133 questionnaires, 109 were properly filled, while 24 were not filled. None was however returned or retrieved unfilled. This is tabulated in table 1 . The table also shows the percentage of state of retrieved questionnaires.

From the table, $81.9 \%$ of the questionnaires were properly filled, $18.05 \%$ were not properly filled, while none was returned or retrieved blank.

Table 1: the percentage of state of retrieved questionnaires

\begin{tabular}{|l|l|l|l|}
\hline S/N & State of questionnaires & Response & Percentage \\
\hline 1 & Properly filled & 109 & 8.95 \\
\hline 2 & Not properly filled & 24 & 18.05 \\
\hline 3 & Blank & 0 & 0 \\
\hline & Total & 133 & 100 \\
\hline
\end{tabular}

Table 2: Number of respondents from each part of the research area

\begin{tabular}{|l|l|l|l|l|}
\hline S/N & Part of research area & Number of respondents & $\begin{array}{l}\text { Expected number of } \\
\text { respondents }\end{array}$ & Difference \\
\hline 1 & Ogwuonu-Igbalapa & 12 & 15 & 3 \\
\hline 2 & Sabon Gari & 21 & 22 & 1 \\
\hline 3 & GRA & 23 & 23 & 0 \\
\hline 4 & Effia & 10 & 14 & 4 \\
\hline 5 & Zone H/B & 10 & 12 & 2 \\
\hline 6 & Eupi & 22 & 22 & 0 \\
\hline 7 & Ojira & 12 & 13 & 1 \\
\hline 8 & Babylon & 9 & 13 & 4 \\
\hline 9 & Oweto & 14 & 16 & 2 \\
\hline & Total & $\mathbf{1 3 3}$ & $\mathbf{1 5 0}$ & $\mathbf{1 7}$ \\
\hline & Percentage 88.67 & $\mathbf{1 0 0}$ & $\mathbf{1 1 . 3 3}$ & \\
\hline
\end{tabular}

From table 2 above, a total of 23 questionnaires distributed to the residents of GRA were all retrieved. This is largely because of the high level of education and enlightenment among the residents. Similarly, the complete number of questionnaires distributed to the residents of Eupi was retrieved. In this case, the reason is particularly because one of the researchers is residing in this part of the research area.

On the whole, out of the 150 (100\%) expected number of respondents, only 133 residents, representing $88.67 \%$ actually responded to the questionnaires. However, a total number of 17 residents, representing $11.33 \%$ did not return the questionnaires distributed to them.

Table 3: Summary of response on occupation of respondents from the sampled areas

\begin{tabular}{|l|l|l|l|l|l|l|l|}
\hline S/No & Sampled area & Civil servant & $\begin{array}{l}\text { Private } \\
\text { business }\end{array}$ & Student & Farmer & House wife & None of the above \\
\hline 1 & Oguonu-Igbalapa & 5 & 1 & 6 & 0 & 0 & 0 \\
\hline 2 & Sabon Gari & 5 & 2 & 10 & 1 & 3 & 9 \\
\hline 3 & GRA & 6 & 5 & 11 & 0 & 1 & 0 \\
\hline 4 & Effa & 6 & 5 & 11 & 0 & 1 & 0 \\
\hline 5 & Zibe H/B & 5 & 0 & 4 & 0 & 0 & 1 \\
\hline 6 & Eup & 13 & 3 & 2 & 1 & 1 & 2 \\
\hline 7 & Ojira & 5 & 4 & 2 & 0 & 1 & 1 \\
\hline 8 & Babylon & 2 & 2 & 2 & 2 & 0 & 1 \\
\hline 9 & Oweto & 4 & 5 & 4 & 0 & 1 & $\mathbf{5}$ \\
\hline & Total & $\mathbf{4 8}$ & $\mathbf{2 2}$ & $\mathbf{4 5}$ & $\mathbf{5}$ & $\mathbf{9}$ & $\mathbf{4}=\mathbf{1 3 3}$ \\
\hline & Percentage & $\mathbf{3 6 . 0 9}$ & $\mathbf{3 3 . 8 3}$ & $\mathbf{3 . 7 6}$ & $\mathbf{6 . 7 7}$ \\
\hline
\end{tabular}


From table 3 above, it is noticed that two categories of respondents form the majority. These include civil servants and students. The former has a total number of 48 respondents, representing 36.09\%, whereas the latter has a total number of 45 respondents, representing $33.83 \%$. Combining these two yields a total number of 93 respondents out of 133 , with an approximate of $70 \%$. With this high percentage response coming from one of the most literate and enlighten classes of the society, it shows that the views expressed in this research work can be generally accepted.

Table 4: Summary of respondents on how long respondents have lived in their area

\begin{tabular}{|l|l|l|l|l|l|l|l|}
\hline S/N & Sampled area & Under 1 yr & $\mathbf{2 - 5 y r s}$ & $\mathbf{6 - 1 0 y r s}$ & $\mathbf{1 - 1 5 y r s}$ & $\mathbf{1 6 - 2 0 y r s}$ & $\mathbf{2 1 y r s ~ \& ~ a b o v e ~}$ \\
\hline 1 & Ogwuonu-Igbalapa & 0 & 7 & 3 & 1 & 1 & 0 \\
\hline 2 & Sabon Gabon & 1 & 5 & 4 & 5 & 4 & 2 \\
\hline 3 & GRA & 1 & 6 & 8 & 2 & 3 & 3 \\
\hline 4 & Effa & 2 & 4 & 1 & 2 & 0 & 1 \\
\hline 5 & Zone H/B & 1 & 4 & 2 & 1 & 1 & 1 \\
\hline 6 & Eupi & 4 & 8 & 4 & 4 & 1 & 1 \\
\hline 7 & Ojira & 2 & 1 & 2 & 2 & 2 & 3 \\
\hline 8 & Babylon & 1 & 3 & 2 & 1 & 2 & 0 \\
\hline 9 & Oweto & 1 & 4 & 3 & $\mathbf{2 1}$ & $\mathbf{1 4}$ & 2 \\
\hline & Total & $\mathbf{1 3}$ & $\mathbf{4 2}$ & $\mathbf{2 9}$ & $\mathbf{1 5 . 7 9}$ & $\mathbf{1 0 . 5 3}$ & $\mathbf{1 0 . 5 3 = 1 0 0}$ \\
\hline
\end{tabular}

From table 4 above, it is obvious that majority of the respondents have lived in the sampled area for a reasonable period of time. For instance, a total of 120 respondents, representing $90.23 \%$ have lived in the sampled area from two years and above. Within this range, majority of them, 42 in number, representing $31.58 \%$ have lived in their area from two to five years. Those who have lived in their area from six to ten years, representing $21.80 \%$, follow this group of respondents. The views of these respondents can be taken as authentic.

Table 5: Summary of respondents on the state of roads

\begin{tabular}{|c|c|c|c|c|c|c|c|}
\hline s/no & Sampled area & Very good & Good & Very good & Bad & Average & $\begin{array}{l}\text { None of the } \\
\text { above }\end{array}$ \\
\hline 1 & $\begin{array}{l}\text { Ogwuonu- } \\
\text { Igbalapa }\end{array}$ & 0 & 2 & 9 & 1 & 0 & 0 \\
\hline 2 & Sabon Gabon & 0 & 0 & 8 & 7 & 6 & 0 \\
\hline 3 & GRA & 0 & 3 & 12 & 4 & 4 & 0 \\
\hline 4 & Effa & 1 & 0 & 2 & 5 & 2 & 0 \\
\hline 5 & Zone H/B & 0 & 2 & 4 & 2 & 2 & 0 \\
\hline 6 & Eupi & 0 & 3 & 6 & 8 & 5 & 0 \\
\hline 7 & Ojira & 0 & 4 & 6 & 2 & 0 & 0 \\
\hline 8 & Babylon & 0 & 0 & 5 & 3 & 1 & 0 \\
\hline \multirow[t]{3}{*}{9} & Oweto & 0 & 1 & 7 & 3 & 3 & 0 \\
\hline & Total & 1 & 15 & 59 & 35 & 23 & $0=133$ \\
\hline & Percentage & 0.75 & 11.28 & 44.36 & 26.32 & 17.29 & $0=100$ \\
\hline
\end{tabular}

From the results as presented in table 5 above, many respondents, 59 in number, constituting $44.36 \%$, agree that the roads are very bad; whereas $35 \mathrm{of}$ them, representing $26.32 \%$ say the roads are in bad state. Combining these two percentages yields $70.68 \%$ - which means that the state of Otukpo Urban roads is generally deplorable.

Table 6: Summary of response on whether or not roads are maintained

\begin{tabular}{|l|l|l|l|l|}
\hline s/no & Sampled area & Yes & No & Do not know \\
\hline 1 & Ogwuonu-Igbalapa & 1 & 10 & 1 \\
\hline 2 & Sabon Gabon & 5 & 16 & 0 \\
\hline 3 & GRA & 11 & 12 & 0 \\
\hline 4 & Effa & 2 & 8 & 0 \\
\hline 5 & Zone H/B & 2 & 8 & 0 \\
\hline 6 & Eupi & 11 & 11 & 0 \\
\hline 7 & Ojira & 2 & 10 & 0 \\
\hline 8 & Babylon & 3 & 5 & 1 \\
\hline 9 & Oweto & 4 & 10 & 0 \\
\hline & Total & $\mathbf{4 1}$ & $\mathbf{9 0}$ & $\mathbf{2}=\mathbf{1 3 3}$ \\
\hline & Percentage & $\mathbf{3 0 . 8 3}$ & $\mathbf{6 7 . 6 7}$ & $\mathbf{1 . 5 0}-\mathbf{1 0 0}$ \\
\hline
\end{tabular}

A total of 90 respondents, constituting $67.67 \%$ say that the roads are not maintained. This is a popular view. However, 41 respondents representing 30.83\% say that the roads in their area are maintained. Only an insignificant number of respondents -2- are undecided. This represents $1.50 \%$.

From the results revealed above, it becomes established that most roads in Otukpo Urban are not maintained. This revelation should be a source of worry for the government and the people alike. 
Table 7: Summary of respondents on who does the maintenance of roads

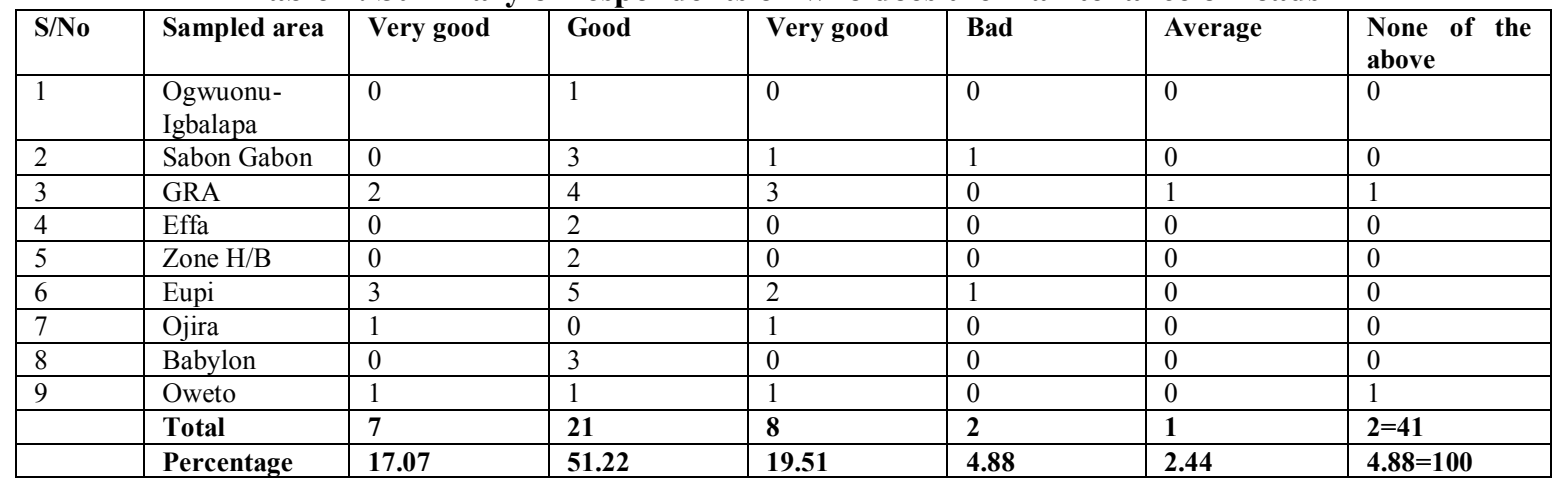

Table 7 above shows that majority of the respondents -21 in number, and constituting $51.22 \%$ of the entire respondents, carry out maintenance of road themselves. However, the second in majority of respondents reveal that it is labourers that do the maintenance. Respondents who say that it is the government that does the maintenance closely follow this. The number of these respondents is just 7, representing only $17.07 \%$. For the government to take a distant third position goes to show its lack of proper commitment in the discharge of its responsibility.

Table 8: Summary of response on who pays labourers to maintain roads

\begin{tabular}{|l|l|l|l|l|l|}
\hline S/No & Sampled area & Government & Resident & NGOs & Do not know \\
\hline 1 & Ogwuonu-Igbalapa & 0 & 0 & 0 & 0 \\
\hline 2 & Sabon Gabon & 1 & 0 & 0 & 0 \\
\hline 3 & GRA & 1 & 2 & 0 & 0 \\
\hline 4 & Effa & 0 & 0 & 0 & 0 \\
\hline 5 & Zone H/B & 0 & 0 & 0 & 0 \\
\hline 6 & Eupi & 0 & 1 & 1 & 0 \\
\hline 7 & Ojira & 1 & 0 & 0 & 0 \\
\hline 8 & Babylon & 0 & 0 & 0 & 0 \\
\hline 9 & Oweto & 0 & $\mathbf{3}$ & 0 & 0 \\
\hline & Total & $\mathbf{3 7 . 5}$ & $\mathbf{4}$ & 0 \\
\hline & Percentage & $\mathbf{4}$ & $\mathbf{1}$ & $\mathbf{0}$ \\
\hline
\end{tabular}

From table 8 above, $50 \%$ of the respondents say that it is the residents that pay the labourers that do the maintenance of roads; whereas $37.5 \%$ of them say it is the government that pays the labourers, while on $y$ $12.5 \%$ agrees that it is the NGOs that pay the labourers.

Given the above statistics, it can be deduced that majority of the respondents are of the view that it is the residents that pay the labourers. This popular view is an indictment on the government for its failure to live up to expectation.

Table 9: Summary of responses on how often is road maintenance done

\begin{tabular}{|l|l|l|l|l|l|l|l|}
\hline S/No & Sampled area & Every day & $\begin{array}{l}\text { Twice } \\
\text { weekly }\end{array}$ & Once a week & $\begin{array}{l}\text { Once a } \\
\text { month }\end{array}$ & At irregular interval & Do not know \\
\hline 1 & Ogwuonu-Igbalapa & 0 & 0 & 0 & 0 & 1 & 0 \\
\hline 2 & Sabon Gabon & 0 & 0 & 0 & 2 & 3 & 0 \\
\hline 3 & GRA & 0 & 1 & 0 & 1 & 8 & 1 \\
\hline 4 & Effa & 0 & 0 & 0 & 1 & 1 & 0 \\
\hline 5 & Zone H/B & 0 & 0 & 0 & 1 & 1 & 0 \\
\hline 6 & Eupi & 0 & 0 & 0 & 0 & 11 & 0 \\
\hline 7 & Ojira & 0 & 0 & 0 & 0 & 2 & 0 \\
\hline 8 & Babylon & 0 & 0 & 0 & 2 & 1 & 0 \\
\hline 9 & Oweto & 0 & 1 & 0 & 0 & 2 \\
\hline & Total & $\mathbf{0}$ & $\mathbf{2}$ & $\mathbf{0}$ & $\mathbf{6}$ & $\mathbf{3 1}$ & $\mathbf{2}$ \\
\hline & Percentage & $\mathbf{0}$ & $\mathbf{0}$ & $\mathbf{1 4 . 6 3}$ & $\mathbf{7 5 . 6 1}$ \\
\hline
\end{tabular}

Table 9 above reveals that even though many states in Nigeria now approve that environmental sanitation be done once in a month, majority of the respondents, representing $75.61 \%$, still embark on road maintenance at irregular intervals. This is an indication of the people's sincere commitment towards the maintenance of public infrastructure. Unfortunately, only $14.63 \%$ of the respondents participate in road maintenance once in a month - which is probably the day declared by government as Environmental Sanitation Day. By this survey, it can be adduced that the people are disenchanted with government policies; hence majority of them are indisposed to maintaining roads on Environmental Sanitation Days. 
Table 10: Summary of response on whether or not residents have drainages in their area

\begin{tabular}{|l|l|l|l|l|}
\hline S/no & Sampled area & Yes & No & Do not know \\
\hline 1 & Ogwuonu-Igbalapa & 8 & 4 & 0 \\
\hline 2 & Sabon Gabon & 3 & 18 & 0 \\
\hline 3 & GRA & 22 & 1 & 0 \\
\hline 4 & Effa & 3 & 7 & 0 \\
\hline 5 & Zone H/B & 6 & 4 & 0 \\
\hline 6 & Eupi & 13 & 9 & 0 \\
\hline 7 & Ojira & 4 & 8 & 0 \\
\hline 8 & Babylon & 2 & 7 & 0 \\
\hline 9 & Oweto & 13 & 9 & 0 \\
\hline & Total & $\mathbf{7 4}$ & $\mathbf{5 9}$ & $\mathbf{0}=\mathbf{1 3 3}$ \\
\hline & Percentage & $\mathbf{5 5 . 6 4}$ & $\mathbf{4 4 . 3 6}$ & $\mathbf{0}=\mathbf{1 0 0}$ \\
\hline
\end{tabular}

Table 10 above indicates that majority of the respondents who were 74 in number, representing $55.64 \%$, agree that they have drainages in their area. A number of them, 59 in number, and representing $44.36 \%$, are however unanimous that they do not have drainages in their area.

Meanwhile, the popular view as expressed by majority of the respondents is an indication of the people's sincerity in acknowledging the availability of certain public infrastructure. Their assessment is thus without bias, as absence of particular infrastructure does not make them cast general aspersions on the government.

Another important observation was about those respondents who do not have drianges in their area. Their percentage (44.36\%) is on the high side. This implies that in Otukpo Urban, there are many roads without drainages. This is an unfortunate development as the consequences of this negligence are better imagined than seen.

Table 11: Summary of responses on the state of drainages

\begin{tabular}{|c|c|c|c|c|c|c|c|}
\hline S/No & Sampled area & Very good & Good & Very bad & Bad & Average & $\begin{array}{l}\text { None of the } \\
\text { above }\end{array}$ \\
\hline 1 & $\begin{array}{l}\text { Ogwuonu- } \\
\text { Igbalapa }\end{array}$ & 1 & 0 & 5 & 2 & 0 & 0 \\
\hline 3 & GRA & 1 & 4 & 7 & 6 & 4 & 0 \\
\hline 4 & Effa & 0 & 0 & 1 & 1 & 1 & 0 \\
\hline 5 & Zone H/B & 0 & 0 & 1 & 2 & 3 & 0 \\
\hline 7 & Ojira & 0 & 1 & 3 & 0 & 0 & 0 \\
\hline 8 & Babylon & 0 & 0 & 0 & 0 & 2 & 0 \\
\hline \multirow[t]{3}{*}{9} & Oweto & 0 & 2 & 5 & 3 & 3 & 0 \\
\hline & Total & 2 & 7 & 26 & 23 & 16 & $0=74$ \\
\hline & Percentage & 2.70 & 9.46 & 35.14 & 31.08 & 21.62 & $0=100$ \\
\hline
\end{tabular}

From the statistics as tabulated in table 11 above, it was obvious that the state of drainages in Otukpo Urban is deplorable. The two highest percentages of $35.14 \%$ and $31.08 \%$ respectively are the basis for this assertion. This is because if the percentage of those who say that the state of drainages in their area is in very bad state and those who agree that their drainages are only in bad state are added up, the resulting percentage $66.22 \%$-forms a majority view. Trailing this popular view is a distant $21.62 \%$, representing those who believe that the state of roads in their area is on the average. Only insignificant percentages of $9.46 \%$ and $2.70 \%$ affirm that the state of drainages in their area is good and very good respectively. These respondents - who constitute the most affluent and enlightened group in Otukpo Urban - will always ensure that their drainages are kept clean.

Table 12: Summary of response on who does the maintenance of drainages

\begin{tabular}{|c|c|c|c|c|c|c|c|c|}
\hline S/No & Sampled area & Govt. & Residents & NGOs & Labourers & $\begin{array}{l}\text { All of the } \\
\text { above }\end{array}$ & $\begin{array}{l}\text { None of the } \\
\text { above }\end{array}$ & Do not know \\
\hline 1 & Ogwuonu-Igbalapa & 3 & 2 & 0 & 0 & 0 & 2 & 1 \\
\hline 2 & Sabon Gabon & 1 & 1 & 0 & 0 & 0 & 1 & 0 \\
\hline 3 & GRA & 8 & 7 & 0 & 2 & 0 & 5 & 0 \\
\hline 4 & Effa & 0 & 3 & 0 & 0 & 0 & 0 & 0 \\
\hline 5 & Zone H/B & 0 & 4 & 2 & 0 & 0 & 0 & 0 \\
\hline 6 & Eupi & 4 & 6 & 0 & 1 & 1 & 1 & 0 \\
\hline 7 & Ojira & 0 & 2 & 0 & 1 & 0 & 1 & 0 \\
\hline 8 & Babylon & 0 & 2 & 0 & 0 & 0 & 0 & 0 \\
\hline \multirow[t]{3}{*}{9} & Oweto & 2 & 4 & 1 & 3 & 1 & 1 & 1 \\
\hline & Total & 18 & 31 & 3 & 7 & 2 & 11 & $2=74$ \\
\hline & Percentage & 24.32 & 41.89 & 4.05 & 9.46 & 2.70 & 14.86 & $2.70=100$ \\
\hline
\end{tabular}


Just like the popular polls indicate that it was the residents that do the maintenance of roads (see table 7), the same thing happens with drainages as revealed by table 12 above, majority of the respondents do the maintenance of drainages. Trailing far behind the majority are those who agree that it is the government that does the maintenance. These respondents are just 18 in number representing only $24.32 \%$. However, there are some who mention labourers and NGOs as carrying out the maintenance work. Their numbers and percentages are insignificant. See table 12 for details.

TABLE 13: Summary of responses on who pays labourers to maintain drainages

\begin{tabular}{|l|l|l|l|l|l|}
\hline S/No & Sampled area & Government & Residents & NGOs & Do not know \\
\hline 1 & Ogwuonu-Igbalapa & 0 & 0 & 0 & 0 \\
\hline 2 & Sabon Gabon & 0 & 0 & 0 & 0 \\
\hline 3 & GRA & 0 & 0 & 2 & 0 \\
\hline 4 & Effa & 0 & 0 & 0 & 0 \\
\hline 5 & Zone H/B & 0 & 0 & 0 & 0 \\
\hline 6 & Eupi & 0 & 1 & 0 & 0 \\
\hline 7 & Ojira & 0 & 0 & 0 & 0 \\
\hline 8 & Babylon & 0 & 0 & 0 & 0 \\
\hline 9 & Oweto & $\mathbf{1}$ & 2 & 0 & 0 \\
\hline & Total & $\mathbf{1 4 . 2 9}$ & $\mathbf{5}$ & 1 & $\mathbf{1}$ \\
\hline & Percentage & $\mathbf{7 1 . 4 3}$ & $\mathbf{1 4 . 2 9}$ & $\mathbf{0}=\mathbf{0}$ \\
\hline
\end{tabular}

Table 13 above follows the same pattern as table 8 . From table 13, it can be seen that majority of the respondents, representing $71.43 \%$ are unanimous that it was the residents that pay the labourers that carry out the maintenance of drainages. Those who assert that it was rather the government and NGOs that pay the labourers are trialing this popular view.

Table 14: Summary of response on how often is drainage maintenance done

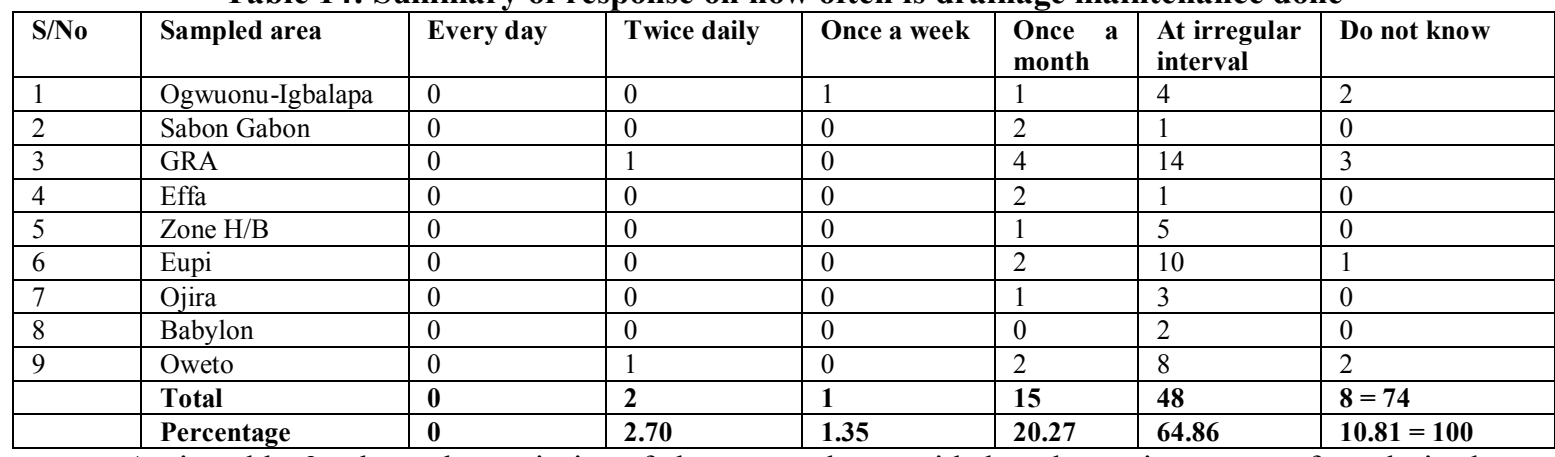

As in table 9 where the majority of the respondents said that the maintenance of roads is done at irregular intervals, table 14 also follows the same trend. The table reveals that 48 of the respondents, representing $64.86 \%$ and constituting the popular view, said that the maintenance of drainages in their area was done at irregular intervals. This is followed by far distant $20.27 \%$, representing the collective view of those who concur that the maintenance of drainages in their area is done once in a month.

Table 15: Summary of responses on whether or not the state of roads and drainages affect respondents negatively

\begin{tabular}{|l|l|l|l|l|}
\hline S/No & Sampled area & Yes & No & Do not know \\
\hline 1 & Ogwuonu-Igbalapa & 10 & 2 & 0 \\
\hline 2 & Sabon Gabon & 21 & 0 & 0 \\
\hline 3 & GRA & 21 & 2 & 0 \\
\hline 4 & Effa & 9 & 1 & 0 \\
\hline 5 & Zone H/B & 9 & 1 & 0 \\
\hline 6 & Eupi & 9 & 0 & 0 \\
\hline 7 & Ojira & 8 & 3 & 0 \\
\hline 8 & Babylon & 12 & 1 & 0 \\
\hline 9 & Oweto & $\mathbf{1 2 1}$ & 2 & 0 \\
\hline & Total & $\mathbf{5 5 . 6 4}$ & $\mathbf{1 2}$ & $\mathbf{0}=\mathbf{1 3 3}$ \\
\hline & Percentage & $\mathbf{4 4 . 3 6}$ & $\mathbf{0}=\mathbf{1 0 0}$ \\
\hline
\end{tabular}

Table 15 above shows that many respondents are of the opinion that they are negatively affected by the state of roads and drainages in their area. Of the 133 respondents sampled in the entire Otukpo Urba, as much as 121 , reprseenting $90.98 \%$ are unanimous that they suffer one form of negative impact or the other. Only a few respondents -12 in number and representing just $9.02 \%$ feel that they are in no way affected negatively by the state of roads and drainages in Otukpo Urban. 
Table 16: Ways Otukpo Urban residents are affected negatively as a result of the poor state of roads and drainages

\begin{tabular}{|c|c|c|c|c|c|c|c|c|c|c|c|c|c|c|c|c|c|c|c|c|}
\hline $\mathrm{S} / \mathrm{N}$ & $\begin{array}{l}\text { Sample } \\
\text { area }\end{array}$ & TR & PSY & $\mathrm{ECO}$ & $\mathrm{SOC}$ & SP & HT & ENV & $\begin{array}{l}\mathrm{AT} \\
\mathrm{A}\end{array}$ & $\begin{array}{l}\text { TR } \\
+ \\
\text { PS } \\
Y\end{array}$ & $\begin{array}{l}\text { TR } \\
+ \\
\mathrm{EC} \\
\mathrm{O}+ \\
\mathrm{SO} \\
\mathrm{C}+ \\
\mathrm{HT}\end{array}$ & $\begin{array}{l}\text { TR } \\
+ \\
\text { EN } \\
\mathrm{V}+ \\
\text { EN } \\
\mathrm{V}\end{array}$ & $\begin{array}{l}\text { TR } \\
+ \\
\mathrm{SO} \\
\mathrm{C}+ \\
\mathrm{HT} \\
+ \\
\mathrm{EN} \\
\mathrm{V}\end{array}$ & $\begin{array}{l}\text { HT } \\
+ \\
\text { EN } \\
\text { V }\end{array}$ & $\begin{array}{l}\text { TR + } \\
\mathrm{PSY}+ \\
\mathrm{ECO}+ \\
\mathrm{SOC}+ \\
\mathrm{HT}+ \\
\mathrm{ENV}\end{array}$ & $\begin{array}{l}\text { TR + } \\
\text { HT }\end{array}$ & $\begin{array}{l}\text { PSY } \\
+ \\
\text { HT }\end{array}$ & $\begin{array}{l}\text { PSY } \\
+ \\
\text { HT } \\
+ \\
\text { ENV }\end{array}$ & $\begin{array}{l}\text { TR } \\
+ \\
\text { PSY } \\
+ \\
\text { HT }\end{array}$ & NTA \\
\hline 1 & $\begin{array}{l}\text { Ogwuonu- } \\
\text { Igbalapa }\end{array}$ & 3 & 0 & 0 & 0 & 0 & 1 & 0 & 5 & 0 & 0 & 1 & 0 & 0 & 0 & 0 & 0 & 0 & 0 & 0 \\
\hline 2 & $\begin{array}{l}\text { Sabon } \\
\text { Gabon }\end{array}$ & 2 & 0 & 1 & 1 & 0 & 3 & 2 & 11 & 0 & 0 & 0 & 0 & 0 & 1 & 0 & 0 & 0 & 0 & 0 \\
\hline 3 & GRA & 4 & 1 & 1 & 0 & 0 & 2 & 3 & 8 & 1 & 1 & 0 & 0 & 0 & 0 & 0 & 0 & 0 & 0 & 0 \\
\hline 4 & Effa & 3 & 0 & 0 & 2 & 0 & 2 & 1 & 0 & 0 & 0 & 1 & 0 & 0 & 0 & 0 & 0 & 0 & 0 & 0 \\
\hline 5 & Zone $\mathrm{H} / \mathrm{B}$ & 2 & 0 & 0 & 0 & 0 & 2 & 0 & 2 & 0 & 0 & 0 & 1 & 1 & 1 & 0 & 0 & 0 & 0 & 0 \\
\hline 6 & Eupi & 7 & 1 & 0 & 0 & 1 & 1 & 0 & 8 & 0 & 0 & 0 & 0 & 0 & 0 & 1 & 1 & 1 & 1 & 0 \\
\hline 7 & Ojira & 4 & 0 & 0 & 0 & 0 & 2 & 0 & 3 & 0 & 0 & 0 & 0 & 0 & 0 & 0 & 0 & 0 & 0 & 0 \\
\hline 8 & Babylon & 3 & 0 & 0 & 0 & 0 & 0 & 1 & 4 & 0 & 0 & 0 & 0 & 0 & 0 & 0 & 0 & 0 & 0 & 0 \\
\hline \multirow[t]{3}{*}{9} & Oweto & 4 & 2 & 0 & 0 & 0 & 1 & 1 & 1 & 0 & 0 & 0 & 1 & 0 & 1 & 1 & 0 & 0 & 0 & 0 \\
\hline & Total & 32 & 4 & 2 & 3 & 1 & 14 & 8 & 42 & 1 & 1 & 2 & 2 & 1 & 3 & 2 & 1 & 1 & 1 & $0=121$ \\
\hline & $\begin{array}{l}\text { Percentag } \\
\text { e }\end{array}$ & $\begin{array}{l}26 . \\
45\end{array}$ & 3.31 & 1.65 & 2.48 & $\begin{array}{l}0.8 \\
3\end{array}$ & $\begin{array}{l}11 . \\
57\end{array}$ & 6.61 & $\begin{array}{l}34 . \\
71\end{array}$ & $\begin{array}{l}0.8 \\
3\end{array}$ & $\begin{array}{l}1.6 \\
5\end{array}$ & $\begin{array}{l}1.6 \\
5\end{array}$ & $\begin{array}{l}0.8 \\
3\end{array}$ & $\begin{array}{l}2.4 \\
8\end{array}$ & 1.65 & 0.83 & 0.83 & 0.83 & 0 & $0=100$ \\
\hline
\end{tabular}

$\underline{\mathrm{Key}}$

TR - transportation

PSY - $\quad$ Psychological State

ECO - economic

state

SOC - social life

Health condition

ENV - environmental state

SP

Spiritual Life

HT

ATA - $\quad$ all of the above

NTA - none of the above

Table 16 above x-rays the myriad of ways that Otukpo Urban residents are affected negatively as a result of the poor state of roads and drainages. These ways include: transportation, psychological state, economic state, social life, spiritual life, health condition, and environmental state.

From the statistic provided in table 16 , majority of the respondents, representing $34.71 \%$ accept that all the spheres of life identified in the preceding paragraph negatively affect them. On the whole, all the respondents affirm that they are in one way or the other affected negatively by the deplorable state of roads and drainages in Otukpo Urban.

Table 17: Summary of responses on whether or not respondents are satisfied with the level of government's commitment to construction and maintenance of roads and drainages.

\begin{tabular}{|l|l|l|l|l|}
\hline S/No & Sampled area & Yes & No & Do not know \\
\hline 1 & Ogwuonu-Igbalapa & 0 & 12 & 0 \\
\hline 2 & Sabon Gabon & 1 & 20 & 0 \\
\hline 3 & GRA & 3 & 18 & 2 \\
\hline 4 & Effa & 1 & 9 & 0 \\
\hline 5 & Zone H/B & 0 & 9 & 0 \\
\hline 6 & Eupi & 0 & 21 & 0 \\
\hline 7 & Ojira & 0 & 12 & 0 \\
\hline 8 & Babylon & 0 & 9 & 0 \\
\hline 9 & Oweto & $\mathbf{6}$ & 14 & 0 \\
\hline & Total & $\mathbf{4 . 5 1}$ & $\mathbf{1 2 4}$ & $\mathbf{3}=\mathbf{1 3 3}$ \\
\hline & Percentage & $\mathbf{9 3 . 2 3}$ & $\mathbf{2 . 2 6}=\mathbf{1 0 0}$ \\
\hline
\end{tabular}

Table 17 above depicts the level of dissatisfaction of the people towards government's level of commitment in the area of construction and maintenance of roads and drainages. Majority of the respondents, numbering 124, and representing 93.23\%, say that they are not satisfied with government's efforts in this regard. Only a few of them, numbering 6, and representing as small as $4.5 \%$, are however satisfied with the level of commitment on the part of the government. A fewer respondents, numbering 3, and representing $2.26 \%$ are 
undecided. In any case, the popular view is a clear indication of the people's disenchantment in the way and manner that government manages the welfare of its citizens.

Table 18: Summary of Responses on What Respondents Think as to Whether or not the People are Interested in Maintaining Roads and Drainages.

\begin{tabular}{|l|l|l|l|l|}
\hline S/No & Sampled Area & Yes & No & Do not know \\
\hline 1 & Ogwuonu- igbalapa & 6 & 5 & 1 \\
\hline 2 & Sabon Gari & 11 & 6 & 4 \\
\hline 3 & GRA & 10 & 9 & 4 \\
\hline 4 & Effa & 7 & 1 & 2 \\
\hline 5 & Zone H/B & 5 & 5 & 0 \\
\hline 6 & Eupi & 8 & 11 & 3 \\
\hline 7 & Ojira & 2 & 8 & 2 \\
\hline 8 & Babylon & 5 & 4 & 0 \\
\hline 9 & Oweto & 7 & 5 & 2 \\
\hline & Total & 61 & 54 & $18=133$ \\
\hline & Percentage & 45.86 & 40.60 & $13.53=100$ \\
\hline
\end{tabular}

Table 18 above was a perfect example of the resilience of the Nigerian people. Despite the feelings of disenchantment expressed in the preceding table (table 17), respondents are still interested in maintaining the existing roads and drainages. From the statistics as displayed by table 18, majority of the respondents, numbering 61, and representing $45.86 \%$ affirm that they are interested in participating in the maintenance of roads and drainages. However, a significant number of respondents, 56 in number, and which represent $40.60 \%$, are not interested in maintaining roads and drainages. This is a very close contest between the two extremes. It is likely that the $13.53 \%$ undeciding respondents will alter the equation when some of them finally decide to pitch their tent with either of the two extremes.

\section{Discussion}

The study found a high level of dissatisfaction (93:23\%) on the level of government's commitment to construction and maintenance of roads and drainages. This level of disenchantment is precipitated upon the high level of deterioration $(70.68 \%$ and $66.22 \%$ ) of Otukpo Urban roads and drainages, respectively.

The poor state of urban roads and drainages arising largely from lack of government's commitment to construction and maintenance of roads and drainages has been confirmed by Adeyeri (1995); Nwoye (2000). In their separate studies on Enugu Urban Area, Nmegbu (2001) and Udongwo (2002) on Port Harcourt Metropolis; and Ogwuche (2005) on Otukpo Urban.

Respondents in this study also opine that the institutionalization of good governance will translate to a corrupt- free- society in which government funds meant for roads and drainages are judiciously utilized. If government is therefore able to live up to expectation, the people are likely to change their bad attitude and/or orientation. As each side fulfils its responsibility vis- a- vis roads and drainages, Otukpo Urban, like other urban centres in Nigeria, will wear a new look that is reminiscent of developed towns and cities.

\section{Conclusion And Recommendations}

Based on the research findings obtained from the data analysis, the following conclusion is drawn on the state of roads and drainages in Otukpo Urban:

1.The government has been very slack in its responsibility of constructing and maintaining roads and drainages in the research area.

2.Although majority of the respondents are interested in maintaining roads and drainages, such interest does not go beyond a mere verbal expression. Their actions such as indiscriminate dumping of refuse in drainages and other unauthorized places and inactions such as their near failure to practically participate and/or be committed to the maintenance of roads and drainages, have contributed in no small measures to the present poor state of roads and drainages in the research area.

In the light of the foregoing, the following recommendations are made: Good Governance: This will ensure that things are done in the proper way. Good governance can even translate to good economy and corruption-free society. A good economy, for instance, discourages people from abusing their environment.

Education and Proper Enlightenment: The introduction of environmental education at all levels of our educational system will go a long way in creating a sustained enlightenment in the proper management of the environment and structures therein. In addition, electronic media such as radio and television, and the print media such as newspapers and magazines should be used to continually sensitize the populace on the impacts of destroying the environment through mismanagement of infrastructure. 
Instutionalization and Implementation of Legal Framework: Legal provision must be installed and implemented to the letter. This way, defaulters of environmental laws are punished accordingly. This serves as a deterrent to others.

\section{A Total change of Orientation of both People and Government:}

This is very vital in turning things around for the better. Countries such as China and Malaysia that are progressing now started by having a total committeement and attitudinal change towards the development of their nations.

Finally, other researchers should be encouraged to carry out the same research on state of roads and drainages in Otukpo Urban and in other states in Nigeria. This will go a long way in assessing the veracity or otherwise of the results that have arisen from this particular research.

\section{References}

[1]. Adeyeri, J.B. (1995). Maintenance of Highways. Conference paper presented at the 1995 National Engineering Conference of the Nigerian Society of Engineers at Owerri. (Processed).

[2]. Areola, D.A (1978). "Soil and Vegetal Resources", in A Geography of Nigerian Development, Heinemann Educational Books, Ibadan. P. 143

[3]. Cedergren, H.R. (1974). Drainage of Highway and Airfield Pavement. John Wiley lnt. London. Pp. 143-156.

[4]. Iloeje, N.P. (1965). A New Geography of Nigeria, Long mans, London. Pp. 134-140.

[5]. Nmegbu, U.S. (2001). Impact of Po or Drainage System - a case study of Port Harcourt Metropolis, PGD Project, ESUT Environmental Management Programme, Enugu.

[6]. Nwoye, C.E. (2000). Problems of Road Transportation Management in Enugu Urban Area. B.Sc. Project, Department of Geography \& Meteorology; ESUT, Enugu. (Processed).

[7]. Offiong, A. (1997). Maintenance Management and Techniques. KAN International Books, Nsukka. Pp. 49-53.

[8]. Ogwuche, J.A. (2005). Sustainable Livelihoods Approach to Poverty Reduction in Otukpo Urban. Ph. D. Thesis, ESUT Environmental Management Programme, Enugu. (processed).

[9]. Owolabi, A.O. (1995). Sustaining the Construction Industry in Nigeria through Local Materials Metamorphosis and Utilization. A conference paper presented at the 1995 National Engineering Conference of the Nigerian Society of Engineers at Owerri. Pp. 123134.

[10]. Uchegbu, S.N. (2000). Environmental Management and Protection. Precision Printers and Publishers, Enugu. Pp. 34-46.

[11]. Udongwo, U.F. (2002). Urban Ro $\sim$ 'z $\{$ Transportation System in Port Harcourt, its Implications on Socio-Economic Development of the City. M. Sc. Dissertation, ESUT Environmental Management Programme. 